\title{
Causes of overgrazing in Inner Mongolian grasslands: Searching for deep leverage points of intervention
}

\author{
Xuening Fang ${ }^{1,2}$ and Jianguo $\mathrm{Wu}^{3}$
}

\begin{abstract}
The legendary Mongolian Plateau has faced increasing environmental challenges associated with overgrazing, and achieving a sustainability transition for this region needs herders' participation. However, why herders let grasslands be overgrazed even after property rights were privatized - "the tragedy of privatization"-remains unclear. We aimed to understand the causes of overgrazing in Xilingol, Inner Mongolia, and sought deep leverage points of intervention by examining livestock decision-making processes with semi-structured interviews. We found the following: (1) Herders generally recognized grassland degradation with decreased plant diversity and vegetation height. (2) Nearly half of herders were not satisfied with their current quality of life, especially in terms of income, food security, energy security, and clean water. (3) Herders prioritized economic benefits and food provisioning services of grasslands and did not think of overgrazing as an important cause for grassland degradation. (4) Herders tended to protect their own grasslands but over-exploited leased grasslands. (5) Herders tried to keep a high number of livestock without being able to anticipate climatic and economic fluctuations. (6) The government's Forage-Livestock Balance policy was widely ignored by herders. We conclude that herders' zeal for higher living standards, misperceptions about key drivers of grassland degradation, decoupling of herders' income from grasslands, inability to cope with drought, and ineffective policies together constitute the underlying causes for overgrazing. Future grassland policies should focus more on the deep leverage points of intervention including reducing poverty and economic inequality, improving the grassland property system, reconnecting the long-term health of leased grasslands to herders' livelihoods, and developing holistic livestock management strategies that integrate science with herders' traditional ecological knowledge.
\end{abstract}

Key Words: grassland degradation; grassland policy; human-environment system; landscape sustainability; participatory approach; sustainability science

\section{INTRODUCTION}

Sustainability transition of grassland systems is essential for achieving sustainability in the vast dryland regions around the world (MA 2005, Reynolds et al. 2007, Liao et al. 2020a). This is especially true for the grasslands in the Inner Mongolia Plateau, where grasslands not only directly support the livelihoods of local rural communities, but also provide enormous regulating ecosystem services, such as carbon sequestration, water retention, and dust storm control, benefiting the region and beyond (Zhang et al. 2020, Zhao et al. 2020). However, during the past few decades, the Inner Mongolian grasslands have severely degraded (Wu et al. 2015, Fang et al. 2021). Studies have shown that overgrazing is the main driver of grassland degradation in the pastoral area of Inner Mongolia (Tong et al. 2004, Jiang et al. 2006, Fang et al. 2015). To prevent overgrazing, the central government of China has implemented several environmental policies to intervene in herders' use of grasslands by setting maximum allowed stocking rates. However, according to the leverage points theory (Meadows 1999, Abson et al. 2017), such measures as direct restrictions on maximum stocking rates are "shallow leverage points" that are easy to manipulate but ineffective in preventing grassland degradation. "Deep leverage points," which are places in complex systems where small interventions often lead to large changes in system outcomes, are less visible but more powerful and effective in dealing with wicked problems (Fischer and Riechers 2019). Such deep leverage points for resolving the overgrazing problem in the Inner Mongolia grassland region are yet to be fully understood. To achieve this goal, it is critical to understand the underlying social-ecological causes and processes of overgrazing.

Overgrazing has long been studied by rangeland ecologists, environmental scientists, and social scientists, among others. The well-known "tragedy of the commons" assumes that, in a shared and unregulated grassland, individual herders tend to act independently according to their own interests, degrading the shared grassland (Hardin 1968). Three strategies have been proposed to avoid this tragedy: coercive state involvement, privatization, and herder self-governance (Ostrom 1990). China has chosen to privatize the property rights of grasslands (since the enactment of the Grassland Law in 1985) to address this issue. However, given the continued degradation of grasslands (Tong et al. 2004, Jiang et al. 2006), the effectiveness of privatization policy has been questioned.

If overgrazing is the main cause of grassland degradation, why do herders not respond to grassland degradation by reducing stocking rates even after the grasslands are privatized? This paradox, known as the "tragedy of privatization" (Liu et al. 2015), has attracted scientists' attention over the past decade ( $\mathrm{Li}$ et al. 2007, Li and Huntsinger 2011, Li and Li 2012, Liu et al. 2015, Robinson et al. 2017). Several explanations have been proposed to unravel this paradox. First, the privatization of grassland property rights has led to the failure of herders' use of traditional wisdom for grassland management and reduced their ability to adapt to climate change (Li and Huntsinger 2011). Second, offsite forage supply and winter sheds lift up the constraints of

${ }^{1}$ Center for Human-Environment System Sustainability (CHESS), State Key Laboratory of Earth Surface Processes and Resource Ecology (ESPRE), Faculty of Geographical Science, Beijing Normal University, ${ }^{2}$ School of Environmental and Geographical Sciences, Shanghai Normal University, ${ }^{3}$ School of Life Sciences and School of Sustainability, Arizona State University 
Fig. 1. Map of the study area and spatial distribution of grassland types with the locations of interviewed households. The photos of meadow steppe, typical steppe, and desert steppe were taken in Xilingol in August 2019.

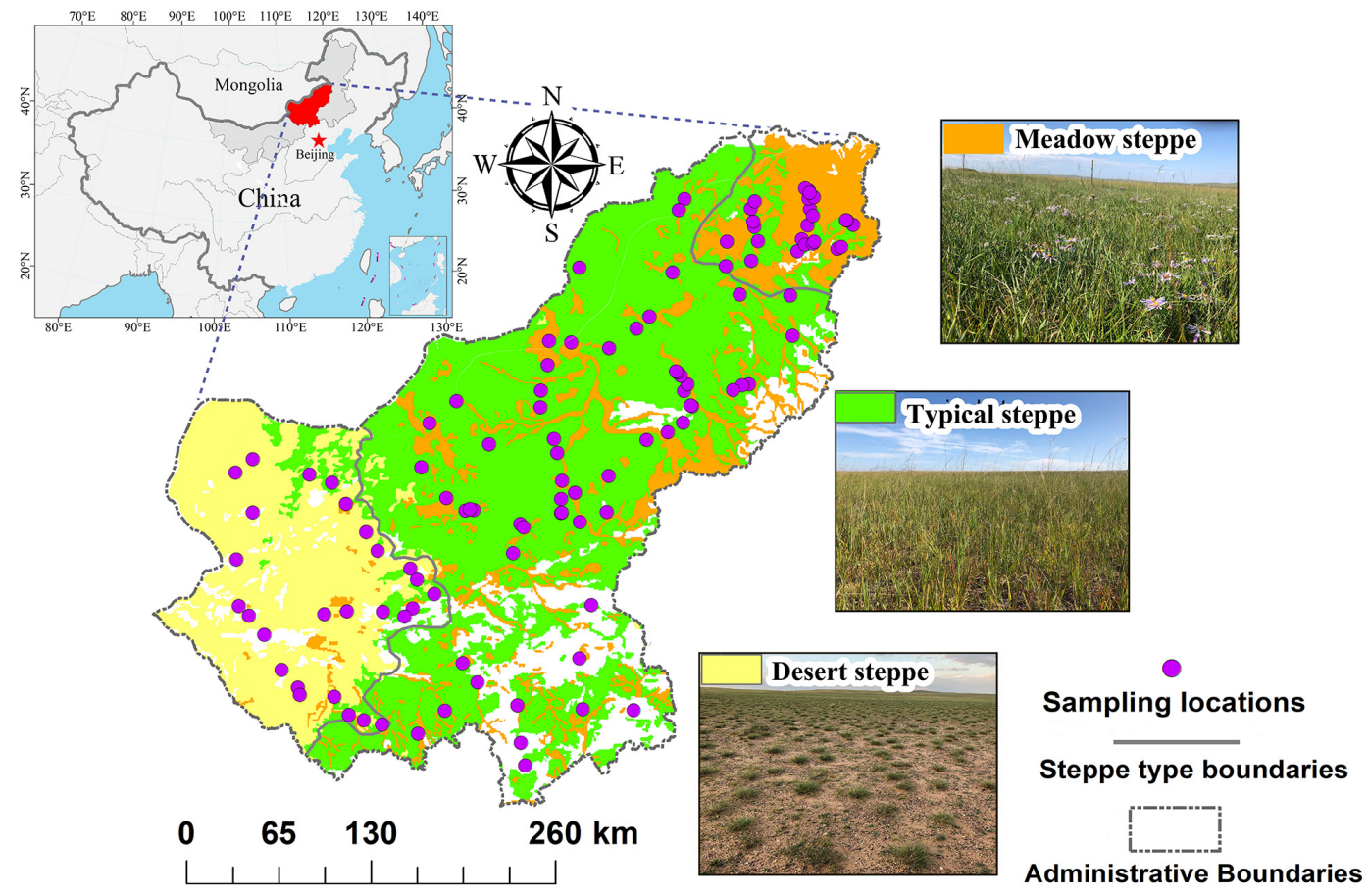

natural grasslands on livestock population growth (Robinson et al. 2017). Third, the unstable, top-down intervention policies not only make herders insecure about future grassland property rights (Robinson et al. 2017), but also gradually decouple the pastoral communities from the grasslands that their livelihoods used to depend on (Li and Li 2012). Although the above explanations all seem plausible, they need to be examined with empirical data in order to better understand the underlying causes of the overgrazing problem and to seek deep leverage points to resolve it.

Thus, this study was designed to address four research questions: (1) Was the government's grassland policy effective in slowing down and reversing overgrazing? (2) Why did overgrazing still occur after the grasslands were privatized? (3) Was the herders' quality of life improving? (4) What are the potential deep leverage points to resolve the problem of overgrazing? To address these four research questions, our study was focused particularly on the herders' livestock decision-making processes. According to Meadows (1998), three key points determine decision-making outcomes: goals, perceived states, and intervention strategies. Thus, we used semi-structured interviews to investigate herders' livestock management goals, perceptions of the herder-grassland system, and livestock management strategies, and then used thematic induction and direct quotations to analyze and illustrate herders' perceptions and understanding of grassland degradation.

\section{METHODS}

\section{Study Area}

Xilingol is a prefectural-level administrative region, located in the central part of Inner Mongolia, China (Fig. 1), with a total area of 20.26 million ha $\left(41.4^{\circ}\right.$ to $46.6^{\circ}, 111.1^{\circ}$ to $\left.119.7^{\circ}\right)$ and a population density of about 0.05 persons per hectare (Wu and Loucks 1992, Bai et al. 2004). Under a prevailing continental climate, the Xilingol region has a mean annual temperature of $2.2^{\circ} \mathrm{C}$, with maximal daily temperatures varying between $-24{ }^{\circ} \mathrm{C}$ and $31^{\circ} \mathrm{C}$ and a mean annual precipitation of $278 \mathrm{~mm}$, which declines gradually from $433 \mathrm{~mm}$ in the east to $135 \mathrm{~mm}$ in the west (Li et al. 2012). About $60-80 \%$ of the precipitation falls during the growing season between May and August. With decreasing precipitation, three zonal grassland types are distributed from east to west: meadow steppe, typical steppe, and desert steppe (Wu and Loucks 1992, Bai et al. 2004, Li et al. 2012). Together, grasslands account for approximately $90 \%$ of the total land area of Xilingol. As a traditionally pastoral region inhabited by Mongolians, the grassland not only plays a key role in conserving biodiversity and important ecosystem services, but also directly supports the livelihoods of the majority of residents ( $\mathrm{Wu}$ et al. 2015, Zhao et al. 2020).

During the past several decades, grassland policy in Xilingol has changed substantially, with profound impacts on both grassland ecosystems and herders' well-being. Since China's "reform and opening up" in 1978, the central government has formulated two categories of grassland policies: the land tenure reform during the 
1980s and 1990s and the ecological construction after 2000 (Wu et al. 2015, Li et al. 2018, Fang et al. 2021). The household responsibility system (HRS) was a milestone of land tenure reform. Under the HRS, the grassland ownership belongs to the collective, whereas the "contractual and use rights" belong to herders who can manage their contracted rangelands at will. To ensure the property rights of herders, the government also launched the Fencing Program to demarcate the boundaries of each households' rangeland. The Fencing Program led to the collapse of community cooperation in some places ( $\mathrm{Li}$ and Huntsinger 2011). The grassland tenure reform has greatly spiked herders' enthusiasm to raise livestock, leading to the doubling or even tripling of stocking rates after a few decades (Li et al. 2007). The rapid expansion of grazing pressure over the past decades has greatly reduced the area of natural grasslands. Consequently, conflicts between grassland conservation and economic development in the pastoral region have become increasingly prominent. Recognizing this, the central government of China has implemented several ecological programs to protect grasslands since 2001 (Sun et al. 2018, Frazier et al. 2019), including the Forage-Livestock Balance policy and the No Grazing and Rotational Grazing policy. In the Forage-Livestock Balance policy, the government sets the maximum stocking rates based on the balance between livestock feed required and livestock feed available in the grassland. The No Grazing and Rotational Grazing policy prohibited herders from grazing in severely degraded grasslands during the seedling establishment period (i.e., early growing season) and encouraged them to practice rotational grazing around different seasons.

\section{Conceptual framework}

To search for potential deep leverage points of intervention in the social-ecological systems of the Xilingol grassland, this study followed the leverage points of intervention theory (Meadows 1999). According to Meadows (1999), there are 12 leverage points of intervention in increasing order of effectiveness: (1) constants, parameters, and numbers (such as subsidies, taxes, and standards); (2) the sizes of buffers and other stabilizing stocks, relative to their flows; (3) the structure of material stocks and flows (such as transport networks and population age structures); (4) the lengths of delays, relative to the rate of system change; (5) the strength of negative feedback loops, relative to the impacts they are trying to correct against; (6) the gain around driving positive feedback loops; (7) the structure of information flows (who does and does not have access to what kinds of information); (8) the rules of the system (such as incentives, punishments, and constraints); (9) the power to add, change, evolve, or self-organize system structure; (10) the goals of the system; (11) the mindset or paradigm out of which the system-its goals, structure, rules, delays, and parameters - arises; and (12) the power to transcend paradigms. Abson et al. (2017) further grouped the 12 leverage points into four categories: (1) intention (goals, norms, values, and paradigms); (2) design (structures, rules, and capacities, maybe including physical system structures or information flows); (3) feedback (interactions among system variables); and (4) parameters ("mechanistic features of a system, such as taxes, incentives, and standards, or physical elements of a system, such as sizes of stocks or rates of material flows" [Abson et al. 2017: 32], usually the goals of decision-makers). Abson et al. (2017) called the first two types of leverage points deep leverage points

and the, last two, shallow leverage points. To effectively achieve grassland sustainability transition, we believe that both the shallow and deep leverage points should be identified.

Thus, we modified Meadows' (1998) decision-making framework to explore both shallow and deep leverage points of intervention in the grassland social-ecological systems (Fig. 2). Herders' livestock decision making is a goal-seeking feedback process in which the perceived state of the target system is compared with the livestock management goal, and the discrepancy is then fed back to the target system for intervention. Herders' livestock decision making not only affects grassland ecological conditions, but also directly determines their livelihoods. Thus, we regarded the herder-grassland system as the target system and investigated herders' perceptions and understanding of herder-grassland systems, livestock management goals, and livestock management strategies. Because actionable knowledge for landscape sustainability transition should be credible, salient, and legitimate (Cash et al. 2003, Wu 2013, 2021, Opdam et al. 2018, Cumming and Epstein 2020, Liao et al. 2020b), we linked herders' perceptions and understanding of herder-grassland systems, livestock decision-making goals, and intervention strategies with grassland policies and scientific knowledge.

Fig. 2. The decision-making framework used in this study, in which herders' perceptions and knowledge about the states of herder-grassland systems (1), livestock management goals (2), and livestock management strategies (3) were investigated and integrated with scientific knowledge and grassland policies to identify the underlying causes for and potential leverage points to ameliorate overgrazing.

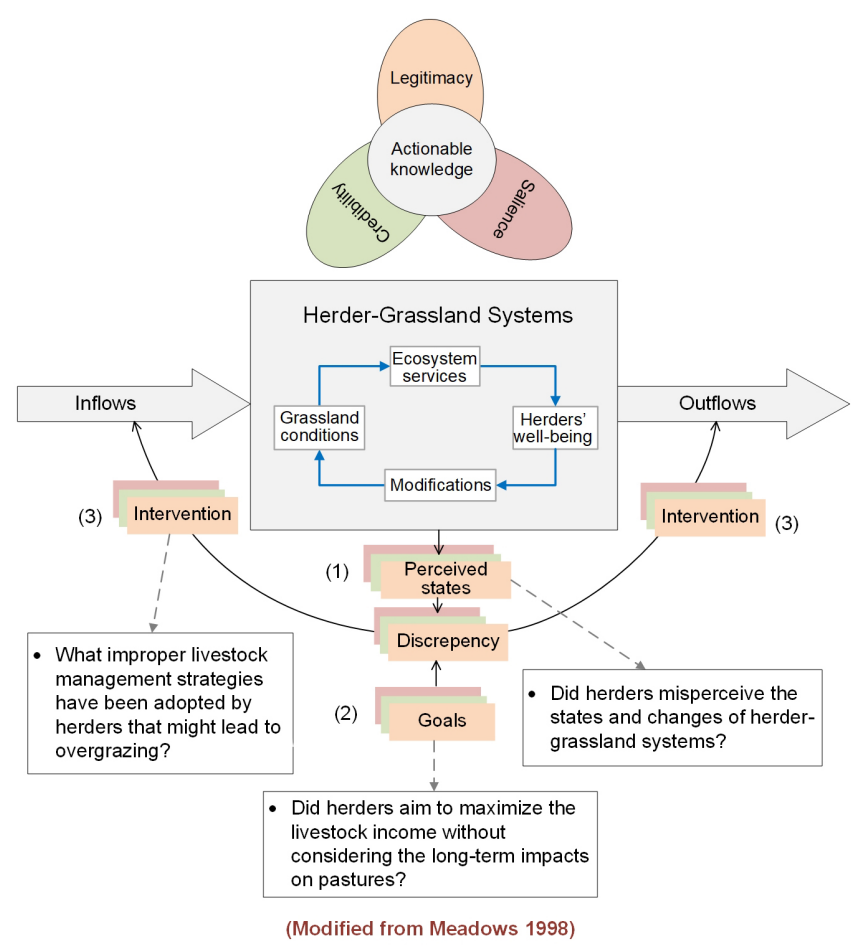

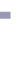




\section{Sampling and data acquisition}

We used a stratified random sampling method to identify potential interviewees. Herder households in the study area were classified into three groups based on grassland ecosystem types (i.e., desert steppe, typical steppe, and meadow steppe). Random sampling was then conducted within each group. Limited by financial and time constraints and guided by conventional sampling protocols, we set the sample size within each grassland type based on population density. Specifically, the sample size for meadow steppe $\left(0.60\right.$ people $\left./ \mathrm{km}^{2}\right)$ was set to 30 , and the sample sizes for desert steppe $\left(0.84\right.$ people $\left./ \mathrm{km}^{2}\right)$ and typical steppe $(1.29$ people $/ \mathrm{km}^{2}$ ) were adjusted according to their population relative to that of meadow steppe. After determining the sample size, we used the spatial random point generation function in GIS to select random households for potential interviewees. Geographical coordinates of the selected samples were then loaded into a Global Positioning System (GPS) device for navigation during fieldwork. When the selected household was inaccessible, we interviewed the nearest herder household instead. In total, we obtained 113 valid samples, including 35 in the desert steppe, 55 in the typical steppe, and 25 in the meadow steppe (Fig. 1).

The Xilingol Statistical Yearbook (Appendix 1) shows that the sex ratio of the population is about one-to-one ( $49 \%$ females and $51 \%$ males). We interviewed more females $(69 \%)$ than males $(31 \%)$, and the age of interviewees ranged from 18 to 60 years. Our sample did not include adolescents and elderly people. Despite the sampling biases, our survey results should be robust for addressing our questions about overgrazing because people aged between 18 and 60 years are the main labor force for grassland livestock management in Inner Mongolia and because the opinions of the interviewees were mostly reflective of those of the households as we understood during the interview.

We conducted semi-structured interviews, between 14 August and 3 September 2019, to investigate herders' perceptions and understanding of herder-grassland systems, livestock management goals, and livestock management strategies. Before starting each interview, we explained the purposes of the data collection and asked for consent from each interviewee, emphasizing that the interviewer was not representing the university, government, or any other entity in a position of political or economic power, and that they were free to decline or withdraw anytime. The family members of interviewees were encouraged to be present if they were available and willing. The interview began with the basic information of herders' demography, livestock management, and livelihoods. We then used a set of questions related to herders' perceptions and understanding of herder-grassland systems, livestock management goals, and livestock management strategies to guide the interview (Fig. 2).

First, to examine herders' perceptions and understanding of the herder-grassland system, we asked them to evaluate grassland vegetation changes, overall well-being conditions, eight specific well-being dimensions (i.e., income, food security, health care, education quality, gender equality, water and sanitation, energy security, and social equity), ecosystem services, and drivers of grassland degradation. Second, to learn if herders were motivated to protect grasslands in livestock management, we asked: why did herders allow for overgrazing even after they recognized its negative impacts on the grasslands? Third, we investigated herders' livestock management strategies in changing conditions by asking how they decided the number of livestock to sell or keep in changing climatic and economic conditions. Finally, we asked herders about their perceptions of grassland environmental policies, including the Fencing Program, Forage-Livestock Balance policy, and No Grazing and Rotational Grazing policy. The detailed questionnaire is included in Appendix 2. According to the interviewee's preference, the language of the interview was either Mandarin Chinese or Mongolian (with the help of a translator). The first author undertook all interviews to ensure consistency in the questioning and recording of responses to the interview questions. The interviews were voice-recorded, transcribed, and translated into English by the first author for analysis.

\section{Data analysis}

We used thematic induction to analyze the qualitative data derived from the interviews (Braun and Clarke 2006). We first started with a deductive approach using the response options for the closedended questions to identify herders' overall perceptions and understanding of grassland vegetation changes, well-being status, the relationship between grazing and grassland degradation, and grassland environmental policies. Then the inductive approach was used to construct codes to classify herders' responses to the open-ended questions including the indicators herders use to judge grassland degradation, herders' explanations for dissatisfaction with life, understanding of the main drivers of grassland degradation, motivations for overgrazing, livestock management strategies, and perceptions of grassland environmental policies. We focused our analysis on herders' explanations of dissatisfaction rather than satisfaction because identifying the causes of dissatisfaction would be more helpful to the government for improving social-economic policies.

The inductive coding process was conducted by hand in Microsoft Word and Excel (version 2016) by the first author and crosschecked by other researchers with similar expertise, according to the following steps (Elo and Kyngä 2008, Fang et al. 2018): first, two coders read the interview transcripts repeatedly to identify the keywords of herders' responses, which were then used to facilitate the initial coding of all the data; second, discrepancies among the coders in their initial coding were solved by heated discussion and recursive feedback from a third coder; third, using techniques described by Bernard (2017; e.g., investigating similarities and differences, checking repetitions, and sorting codes), the resulting codes were grouped into higher level themes by discussion among all the coders for constructing meaningful interpretation. Microsoft Excel 2016 was also used to generate descriptive statistics. We calculated percentages based on the data frequency of codes or categories. Percentages in the text refer to the number of respondents from the immediately mentioned subsample who made that particular statement. To express the original point of view of respondents, direct quotations are used.

\section{RESULTS}

Herders' perceptions and understanding of grassland vegetation changes, herder-grassland relationship, and quality of life

More than half of the herders perceived that the grassland had been degrading after 2001, with fewer plant species and lower vegetation height (Fig. 3). In total, $56 \%$ of herders thought that 
their grasslands had been getting worse over the past 20 years, $25 \%$ found that there had been no changes, and $17 \%$ believed that their grasslands had gotten better (Fig. 3a). As one herder stated,

Fig. 3. Herders' perceptions of changes in grassland vegetation (a), grassland ecosystem services (b), drivers of grassland degradation (c), and the indicators they use to judge grassland degradation (d) in all samples under different grassland types.
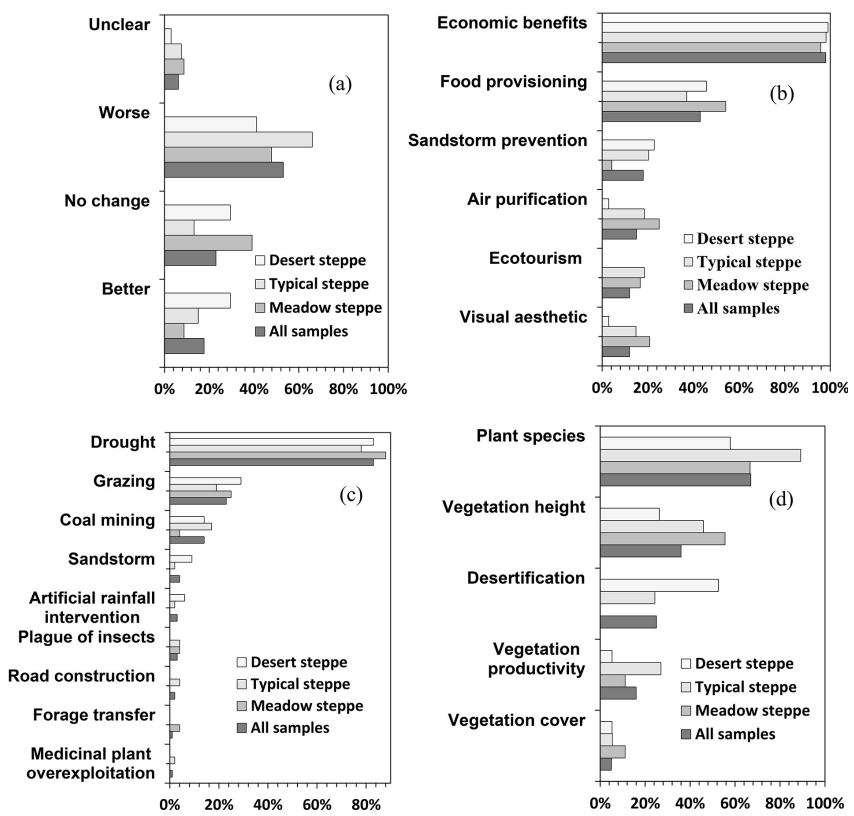

When I was a child, the grass in the grassland was so high that I couldn't see the sheep from a distance. But now the grassland is getting worse every year, and there is not enough grass to feed the sheep.

Herders used five indicators to judge grassland degradation including plant species, vegetation height, desertification, vegetation productivity, and vegetation cover (Fig. 3d). Among these, plant species and vegetation height were the most widely mentioned indicators, with a frequency of $67 \%$ and $36 \%$ of the time, respectively. Herders' perceptions of grassland vegetation change varied by grassland types. Sixty-six percent of herders perceived that typical steppes were getting worse (48\% and $41 \%$ for meadow and desert steppes, respectively), 39\% of herders perceived that meadow steppes were not changing (13\% and $29 \%$ for typical and desert steppes, respectively), $29 \%$ of herders perceived that desert steppes were getting better $(15 \%$ and $9 \%$ for typical and meadow steppes, respectively). The indicators herders used to judge grassland degradation varied with grassland types. For typical and meadow steppes, plant species and vegetation height were the most frequently used indicators whereas, for desert steppes, the most frequently used indicators were plant species and desertification.

Six ecosystem services were identified by herders, including economic benefits, food provisioning, sandstorm prevention, air purification, ecotourism, and visual aesthetics (Fig. 3b). Among them, economic benefits and food provisioning were the most widely mentioned, with $98 \%$ frequency and $43 \%$ frequency, respectively. We identified 10 drivers of grassland degradation in the thematic induction, of which drought was the most frequently mentioned, with $94 \%$ frequency (Fig. 3c). Only 38\% of herders regarded overgrazing as a potential driver of grassland degradation and, among them, fewer than $10 \%$ thought that overgrazing was directly related to grassland degradation. As one herder stated,

\section{I think the main cause of grassland degradation is drought. When the precipitation is sufficient, the grassland can grow well even if there are more livestock, but when drought occurs, the grass will grow poorly even if there are a few livestock grazing on it.}

Herders' perceptions of grassland ecosystem services varied by grassland types. Herders in desert steppes were less likely to perceive air purification $(3 \%)$, ecotourism $(0 \%)$, and visual aesthetics $(3 \%)$. Herders in meadow steppes were less likely to perceive sandstorm prevention $(4 \%)$. Herders' knowledge regarding overgrazing as a factor for grassland degradation seemed to correlate with age and nationality (Appendix 3). A higher proportion of middle-aged herders (35-59 years old, 26\%) than older herders ( $>59$ years old, $17 \%$ ) and young herders $(18$ 34 years old, 14\%) perceived overgrazing as a factor for grassland degradation. A higher proportion of Han (33\%) than Mongolians $(19 \%)$ perceived overgrazing as a factor for grassland degradation.

Herders' satisfaction with their overall quality of life and eight well-being dimensions are presented in Figure 4 . In total, $51 \%$ of herders felt satisfied with their overall quality of life. The overall life satisfaction of herders in typical steppes was much lower, with only $49 \%$ satisfaction compared to $72 \%$ satisfaction in desert and meadow steppes. Although herders' satisfaction with all the eight well-being dimensions exceeded $50 \%$, only income satisfaction was significantly correlated $\left(\mathrm{R}^{2}=0.23, \mathrm{p}<0.05\right)$ with herders' overall life satisfaction (Appendix 4). In addition, $49 \%$ of herders remained dissatisfied with their quality of life, especially in terms of income, food security, access to energy, and clean water. Herders' explanations for dissatisfaction are summarized in Appendix 5 and Figure 5. More than $40 \%$ of herders complained about insufficient income to support a good life and rising economic inequality within the pastoral community. As one herder lamented,

I am not satisfied with my current level of income. Our neighbors have larger grassland areas and can raise more livestock, and their annual income is much more than ours. Now they have bought new cars and built big new houses, but we have nothing.

For food security, herders were concerned with the accessibility $(11 \%)$ and safety of eating $(12 \%)$ vegetables and fruits: on the one hand, the vegetables and fruits in pastoral areas were expensive and inconvenient to purchase; on the other hands, herders were worried about the excessive use of pesticides and fertilizers for vegetables and fruits from the markets. Insufficient water supply and poor water quality were also problems for herders: $16 \%$ of herders complained that the water quality was poor with high salinity, $12 \%$ of herders stated that their water supply was insufficient for livestock, and 5\% of herders mentioned that coal mining was polluting and depleting their water sources. For energy 
Fig. 4. Herders' subjective evaluations of the overall quality of life and eight specific well-being dimensions related to the Sustainable Development Goals (SDGs) in all samples under different grassland types.

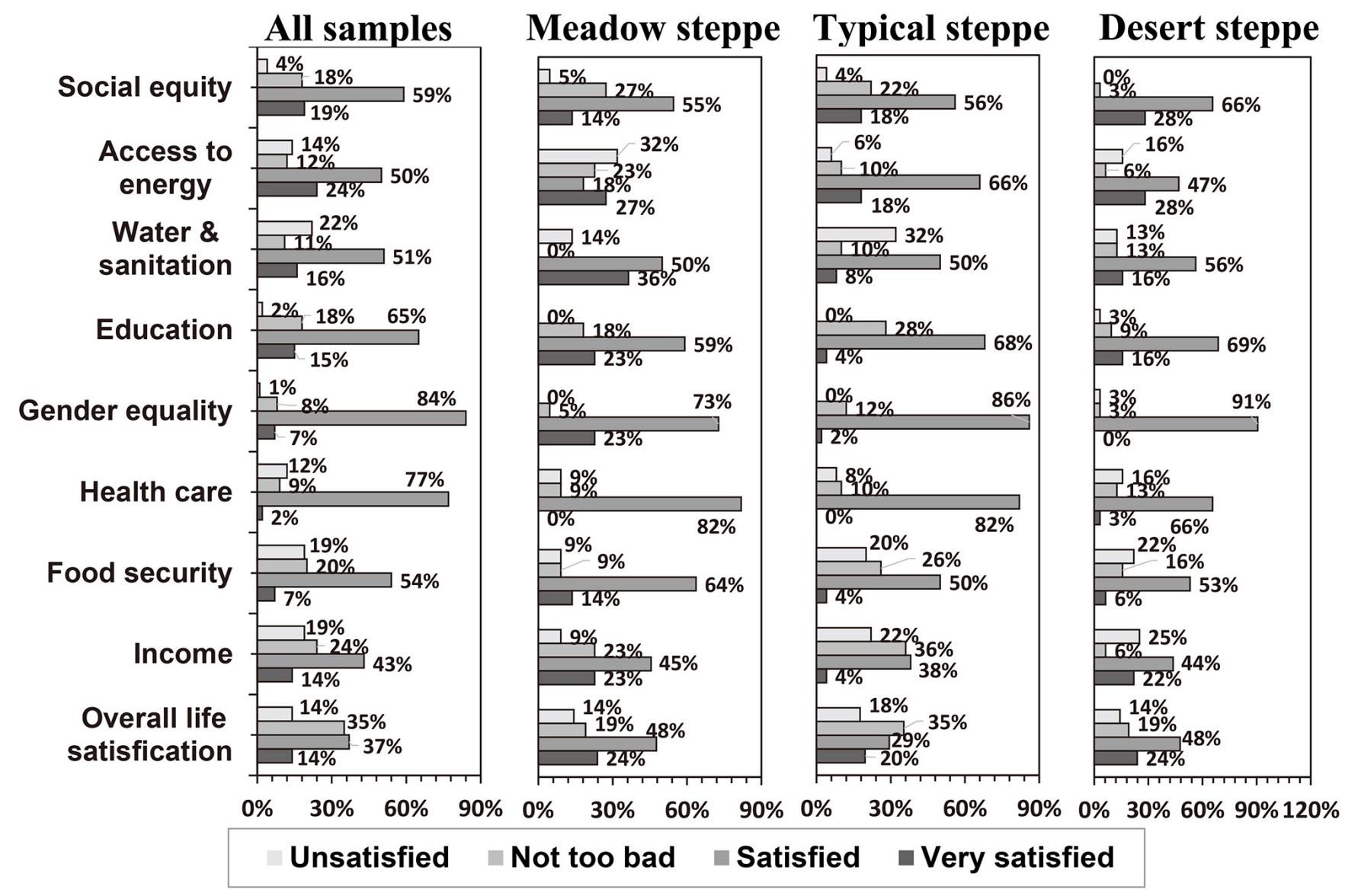

use, although most herders had access to the electricity generated by solar and wind power, $15 \%$ complained that electricity was unstable and insufficient for daily use.

Fig. 5. The current status of the four well-being dimensions that herders were most unsatisfied with including poverty (a), concerns about the safety of vegetables and fruits (b), unstable energy supply (c, d), and shortage of safe drinking water (e, f). All the photos were taken in Xilingol in August 2019.

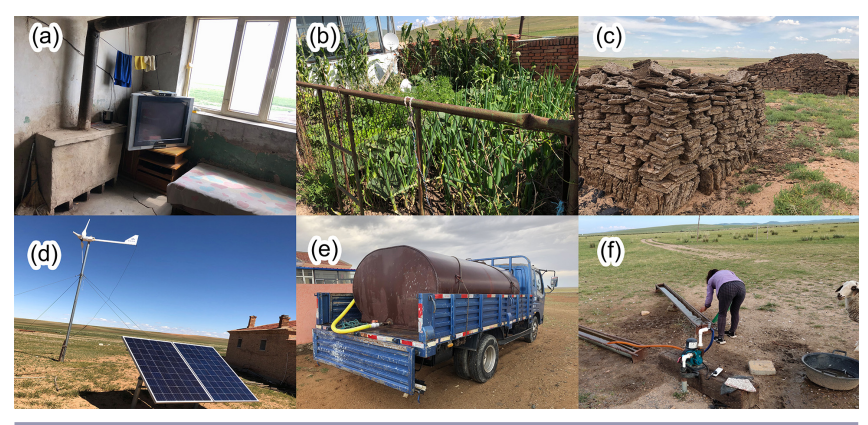

Herders' motivations for overgrazing in livestock management We identified six explanations for overgrazing, which can be grouped into three categories (Table 1). The most frequently mentioned reason was the increased economic pressure: on the one hand, the basic living expenditures for food, education, and traffic increased rapidly (65\% of respondents) during recent decades; on the other hand, the pressure of repaying loans also forced herders to raise more livestock $(16 \%)$. As one herder stated,

I can only earn more money by raising more sheep. For the future of my three children, I sent all of them to school in the city of the county. My wife rented an apartment in the city to take care of them. The annual expenses are very high, and we still have a loan from last year's forage purchase. I know that having more sheep is not good for the grassland, but I have no choice.

The transaction of pasture property rights was another frequently mentioned reason for overgrazing. Herders complained that renting pasture was very expensive $(24 \%)$. Because the subsidies of pasture went to pasture contractors $(22 \%)$, the renters had to raise more livestock to make a profit. Furthermore, some herders 
thought that overgrazing was a result of ineffective grassland policies such as the privation of grassland property $(11 \%)$ and the Fencing Program (11\%). As one herder said,

\begin{abstract}
Both my father and grandfather grazed on this grassland. Based on the current pasture allocation policy, pasture areas per household do not change as population changes. Thus, over years, as pasture property right is handed down by inheritance, the sons receive smaller and smaller pasture areas, with more and more people in the family depending on it. And because our pasture is small, we have to overstock to feed our family.
\end{abstract}

Table 1. Herders' explanations for overgrazing.

\begin{tabular}{lcl}
\hline \hline $\begin{array}{l}\text { Why do herders overstock even after } \\
\text { recognizing its negative effects on } \\
\text { grasslands? }\end{array}$ & $\begin{array}{l}\text { Frequency } \\
(\mathrm{n}=37)\end{array}$ & Categories \\
\hline $\begin{array}{l}\text { The basic living expenditure (e.g., the } \\
\text { expenditure on food, education, and } \\
\text { traffic) increased rapidly. }\end{array}$ & $65 \%$ & $\begin{array}{l}\text { Increased economic } \\
\text { pressures }\end{array}$ \\
$\begin{array}{l}\text { The pressure of repaying loans. } \\
\text { Renting grasslands is very expensive, } \\
\text { and the renters have to raise more }\end{array}$ & $24 \%$ & $\begin{array}{l}\text { Transaction of } \\
\text { pasture property } \\
\text { livestock to make profits. }\end{array}$ \\
$\begin{array}{l}\text { The subsidies of pasture belong to } \\
\text { pasture contractors, and the outcomes } \\
\text { of overgrazing are borne by the renters. }\end{array}$ & $22 \%$ & $\begin{array}{l}\text { Per capita pasture decreases with the } \\
\text { increasing family size. }\end{array}$ \\
$\begin{array}{l}\text { The Fencing Program leads to } \\
\text { overgrazing. }\end{array}$ & $11 \%$ & $\begin{array}{l}\text { Ineffective grassland } \\
\text { policy }\end{array}$ \\
\hline
\end{tabular}

\section{Herders' livestock management strategies and views on grassland} environmental policies

We identified six factors that influenced the herders' livestock decisions (Table 2). The most frequently mentioned two factors were pasture area $(87 \%)$ and drought $(70 \%)$. Herders stated that pasture size determined how many livestock they planned to raise each year, whereas the occurrence of drought could disrupt their annual plans by forcing additional livestock slaughter. Herders only sell lambs in normal years, but have to sell some ewes as well when drought occurs. Labor shortage was another factor influencing the herd size of a household. About $27 \%$ of herders mentioned that they lacked labor for livestock management because of aging, illness, and young people seeking jobs in urban areas. Some financial factors, including deposit amount $(27 \%)$, loan availability $(19 \%)$, and livestock price $(15 \%)$, also influenced the number of livestock. When herders had enough deposits or could get loans, they tended to increase the number of livestock by renting more grasslands. With deposits and loans, herders were also able to better adapt to droughts by renting grasslands or purchasing supplementary forages. Livestock prices influenced the number of livestock in different ways for the poor and the rich: when the livestock price was low, the poor tended to sell more livestock to maintain the livelihood and repay the loan, whereas the rich tended to reserve more lambs to replace the old ewes.
Table 2. Factors influencing herders' livestock management strategies.

\begin{tabular}{|c|c|c|}
\hline $\begin{array}{l}\text { How do herders decide the number of } \\
\text { livestock to slaughter or stock each year? }\end{array}$ & $\begin{array}{l}\text { Frequency } \\
(\mathrm{n}=88)\end{array}$ & Categories \\
\hline $\begin{array}{l}\text { A larger pasture area can support more } \\
\text { livestock. }\end{array}$ & $87 \%$ & Pasture area \\
\hline $\begin{array}{l}\text { When a drought occurs, herders first try to buy } \\
\text { forages or rent grasslands, but they will } \\
\text { slaughter some ewes if lacking funds. }\end{array}$ & $70 \%$ & Drought \\
\hline $\begin{array}{l}\text { Declining labor capacity due to aging or } \\
\text { diseases leads to lower livestock numbers and } \\
\text { more pasture leasing. }\end{array}$ & $27 \%$ & Workforces \\
\hline $\begin{array}{l}\text { Reduced workers in pastoral areas due to } \\
\text { urbanization leads to lower livestock numbers } \\
\text { and more pasture leasing. }\end{array}$ & & \\
\hline $\begin{array}{l}\text { With more savings, herders can rent more } \\
\text { grasslands and support a larger number of } \\
\text { livestock. } \\
\text { With more savings, herders can cope with } \\
\text { droughts better by purchasing forages or } \\
\text { renting grasslands. }\end{array}$ & $27 \%$ & $\begin{array}{l}\text { Deposit } \\
\text { amount }\end{array}$ \\
\hline $\begin{array}{l}\text { If a loan is available, herders can purchase } \\
\text { more supplementary forages to support a } \\
\text { larger number of livestock. } \\
\text { If a loan is available, herders can cope with } \\
\text { droughts by purchasing forages or renting } \\
\text { grasslands. }\end{array}$ & $19 \%$ & $\begin{array}{l}\text { Loan } \\
\text { availability }\end{array}$ \\
\hline $\begin{array}{l}\text { When the livestock price is low, the poor } \\
\text { herders have to slaughter more livestock to } \\
\text { make a living or pay off the loan. } \\
\text { When the livestock price is low, the rich } \\
\text { herders choose to reserve more lambs to } \\
\text { replace old ewes. }\end{array}$ & $15 \%$ & $\begin{array}{l}\text { Livestock } \\
\text { price }\end{array}$ \\
\hline
\end{tabular}

Herders expressed different views on the Fencing Program, No Grazing and Rotational Grazing policy, and Forage-Livestock Balance policy. In total, $74 \%$ and $53 \%$ of herders were in favor of the Fencing Program and No Grazing and Rotational Grazing policy, respectively, whereas only $24 \%$ of herders supported the Forage-Livestock Balance policy (Table 3). Herders said that the Fencing Program could not only effectively prevent their grasslands from being grazed by others, but also increase the labor efficiency of livestock management. Although some herders complained that the subsidy of the No Grazing and Rotational Grazing policy was low, most of them agreed that this policy was good for plant growth. Herders provided three reasons to explain why they did not support the Forage-Livestock Balance policy. First, $22 \%$ of herders said that the maximum livestock number stipulated by this policy did not match their grasslands' actual carrying capacity. Second, $20 \%$ of herders mentioned that they could adjust the livestock number by themselves based on their grasslands' actual conditions, and that this policy was completely unnecessary. Third, $13 \%$ of herders complained that they would be unable to make a living were they to strictly abide by this policy. As a result, the actual stocking rates of this area were 2-3 times higher than the prescribed stocking rates (Fig. 6). As one herder stated,

The current Forage-Livestock Balance policy is mostly a formality. The government officials occasionally come down to inspect. But before they come, we often get 
Table 3. Herders' views on current grassland environmental policies. The four frequencies in parentheses under the column entitled "Herders' overall views (\%)" represent herders' views from all three steppe types as a whole, meadow steppe, typical steppe, and desert steppe, respectively.

\begin{tabular}{|c|c|c|c|}
\hline $\begin{array}{l}\text { Grassland } \\
\text { environmental } \\
\text { policy }\end{array}$ & $\begin{array}{l}\text { Herders' overall } \\
\text { views }(\%)\end{array}$ & Specific explanation & $\begin{array}{l}\text { Frequency } \\
(\mathrm{n}=94)\end{array}$ \\
\hline \multirow[t]{5}{*}{ Fencing Program } & $\begin{array}{l}\text { Reasonable } \\
(69,90,53,79)\end{array}$ & (1) Fencing facilitates livestock management and increases labor efficiency. & $51 \%$ \\
\hline & & (2) Fencing can prevent grasslands from being grazed by others. & $34 \%$ \\
\hline & $\begin{array}{l}\text { Unreasonable } \\
(21,10,27,21)\end{array}$ & (3) Fencing leads to the uneven distribution of grasslands for herders. & $11 \%$ \\
\hline & & (4) Fencing increases the trampling of grasslands by livestock, leading to pasture degradation. & $5 \%$ \\
\hline & & $\begin{array}{l}\text { (5) Fencing is not good for livestock growth because it can reduce the diversity of livestock } \\
\text { feeds. }\end{array}$ & $4 \%$ \\
\hline \multirow[t]{7}{*}{$\begin{array}{l}\text { Forage-Livestock } \\
\text { Balance policy }\end{array}$} & $\begin{array}{l}\text { Reasonable } \\
(24,19,24,28)\end{array}$ & (1) This policy is beneficial for grass growth. & $24 \%$ \\
\hline & $\begin{array}{l}\text { Unreasonable } \\
(69,81,62,72)\end{array}$ & (2) The maximum stocking rates stipulated by this policy do not match local realities. & $22 \%$ \\
\hline & & $\begin{array}{l}\text { (3) This policy is completely unnecessary because herders can adjust their livestock number } \\
\text { themselves according to climatic conditions. }\end{array}$ & $20 \%$ \\
\hline & & (4) Herders cannot make a living if strict adherence to the policy. & $13 \%$ \\
\hline & & $\begin{array}{l}(5) \text { The subsidy is too low to compensate for the income decline because of lower stocking } \\
\text { rates. }\end{array}$ & $6 \%$ \\
\hline & & (6) This policy is not flexible enough to reflect precipitation fluctuations. & $6 \%$ \\
\hline & & $\begin{array}{l}\text { (7) The allocation of subsidy is irrational: the cost of this policy is borne by renters, but the } \\
\text { subsidy belongs to the owners. }\end{array}$ & $4 \%$ \\
\hline \multirow{5}{*}{$\begin{array}{l}\text { No Grazing } \\
\text { and Rotational } \\
\text { Grazing policy }\end{array}$} & $\begin{array}{l}\text { Reasonable } \\
(53,57,49,55)\end{array}$ & (1) The forbidden grazing during the rejuvenation period is beneficial for grass growth. & $53 \%$ \\
\hline & $\begin{array}{l}\text { Unreasonable } \\
(41,43,38,45)\end{array}$ & (2) The subsidy of this policy is too low to compensate for the costs of forbidden grazing. & $21 \%$ \\
\hline & & $\begin{array}{l}\text { (3) The forbidden grazing is useless, the growth of grass is mainly determined by } \\
\text { precipitation. }\end{array}$ & $13 \%$ \\
\hline & & $\begin{array}{l}\text { (4) The forbidden grazing coincides with the lambing period when the ewes need to feed live } \\
\text { grasses to get enough nutrition. }\end{array}$ & $11 \%$ \\
\hline & & $\begin{array}{l}\text { (5) The allocation of subsidy is irrational: the cost of this policy is borne by renters, but the } \\
\text { subsidy belongs to the owners. }\end{array}$ & $9 \%$ \\
\hline
\end{tabular}

messages via We Chat in advance and hide the sheep from inspection. Even if we are caught overstocking, we are still willing to raise more because we still make a profit after paying the penalty.

\section{DISCUSSION}

Was the government's grassland policy effective in slowing down and reversing overgrazing?

Our results indicate that $81 \%$ of herders did not think that the grassland conditions were improving after 2001, of which $56 \%$ thought that the grasslands were degrading during the past two decades (Fig. 3a). These results seem inconsistent with the ecological findings that reported large-scale grassland restoration (Li et al. 2012, Mu et al. 2013). We examined the relevant literature and found two possible explanations for this discrepancy. First, the satellite image-based vegetation indices alone, which researchers commonly use, may not provide reliable information about grassland degradation. Studies have shown that the Enhanced Vegetation Index of overgrazed areas can be significantly higher than that of ungrazed areas because invasive and unpalatable grass species in overgrazed grasslands often have a denser leaf structure (Karnieli et al. 2013). Second, the literature reporting grassland restoration did not directly report the overall changes in grassland conditions. They either distinguished the
Fig. 6. A comparison between the actual stocking rate and the maximum stocking rate stipulated by the Forage-Livestock Balance Policy.

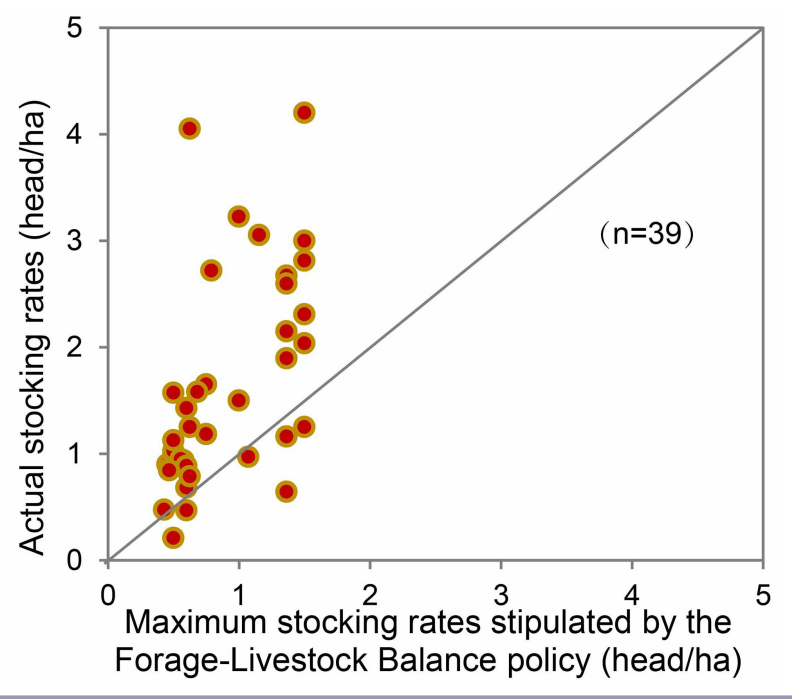


climatic factors and anthropogenic factors ( $\mathrm{Li}$ et al. 2012, John et al. 2016) or reported grassland restoration caused by land conversion (from cropland and desertified land to grassland; $\mathrm{Mu}$ et al. 2013). Those who evaluated the overall grassland conditions also found the productivity of Inner Mongolia declined between 2001 and 2010 (Bao et al. 2014, Miao et al. 2015), and drought was the main driver (Zhao et al. 2015). Thus, the herders' perceptions of grassland vegetation changes were more local, livestock-centered, and holistic, whereas the scientific studies relied heavily on remote sensing data and land cover changes on broad scales. The grassland policies did lead to the conversion of large areas of arable land and desertified land back to grasslands, but this improvement did not seem to have benefited the local herders substantially (thus they did not feel it). Connecting scientific information with traditional ecological understanding could help bridge the knowledge gaps of complex situations through bringing in new perspectives and new types of evidence (Díaz et al. 2018, Biro et al. 2019).

Our analysis indicates that $94 \%$ of herders perceived drought as the most important cause of grassland degradation, but only $38 \%$ of herders believed that grassland degradation was caused by overgrazing (Fig. 3). This is at odds with the findings of most ecological studies that both overgrazing and drought are the main causes of grassland degradation (Liu et al. 2013, Wang et al. 2013, Miao et al. 2015, Zhao et al. 2015). Grassland degradation caused by overgrazing is usually a cumulative and slow process (Hilker et al. 2014), and it is often difficult for herders to notice the slow changes. By contrast, drought has a more acute and severe impact on grasslands (Wu et al. 2014, Miao et al. 2015). Thus, the effects of precipitation fluctuations on grasslands can overshadow the effects of overgrazing. Misunderstanding the causes of grassland degradation can hinder herders from adopting appropriate strategies to cope with it.

We also found that middle-aged herders were more likely than younger herders to consider overgrazing a cause of grassland degradation, and Han Chinese were more likely than Mongolians to consider overgrazing a factor in grassland degradation (Appendix 3). Middle-aged herders usually have more experience in livestock management than younger herders and can accumulate more knowledge about grassland degradation in their daily livestock management. Han herders usually lease more pastures than Mongolian herders (the percentage of leased pasture area to total pasture area for Mongolians and Han Chinese was $46 \%$ and $24 \%$, respectively). More pasture leases can lead to a higher probability of overgrazing and grassland degradation ( $\mathrm{Li}$ et al. 2018). Thus, Han herders are more likely to experience and perceive grassland degradation caused by overgrazing. This result suggests that both the degree of herders' livelihood dependence on grasslands and grassland property rights may have an impact on herders' ecological perceptions. It also suggests that different leverage points can influence each other.

\section{Why did overgrazing still occur after the grasslands were privatized?}

Our results show that nearly $50 \%$ of herders did not feel satisfied with their current quality of life (Fig. 4), indicating that they had a strong desire to increase livestock numbers to improve their income. Whether or not herders considered overgrazing's impacts in their decision making depended on the ownership of grassland property rights and their living standards. Herders generally expressed a willingness to protect their grasslands, but they preferred to maximize the use of leased grasslands because of insecure grassland property rights, high costs, and lack of subsidies (Table 1). Negative environmental impacts of farmland rental, such as long-term over-exploitation of land resources and overuse of pesticides and fertilizers, have been widely reported around the world (Dubois 2002, Carvalho 2017, Clay and Zimmerer 2020). In our case, the poor were not able to protect grasslands by reducing stocking rates because they thought that they would have to raise more livestock to make ends meet and repay loans. As one herder stated,

\section{I know that overgrazing will degrade the grassland, but I have no choice. With such a small piece of grassland, if I do not raise more livestock, I would not be able to support my two children to attend school in the city.}

Both the decoupling of herders' income from local grassland conditions ( $\mathrm{Li}$ and $\mathrm{Li}$ 2012, Robinson et al. 2017) and herders' misperceptions about the drivers of grassland degradation contributed to the herders' lack of response to grassland degradation by reducing stocking rates. Herders cared most about economic profits from grasslands (Fig. 3c), and, with grassland degradation, herders' income still grew rapidly over the past decades (Shang et al. 2019). The decoupling may be caused by supplementary forage from elsewhere (Table 2), which lifted the carrying capacity of local grasslands for livestock (Robinson et al. 2017). In addition, most herders did not recognize that grassland degradation was mainly caused by overgrazing (Fig. 3d). Without understanding the drivers of grassland degradation, herders were unable to adopt ecologically sound strategies to use and manage their grasslands.

Moreover, in a region with highly variable precipitation, herders' strategies to keep overloaded livestock numbers stable year after year were doomed to overgrazing. It is difficult for herders to adjust grazing to precipitation variations without sophisticated forecasting at hand, and even the government's Forage-Livestock Balance policy does not take this into account. Herders used to cope with drought by storing grass locally, but now most herders purchase large amounts of forage to support excessively large livestock populations, regardless of drought. In this case, when a drought occurs, rich herders choose to buy more forage within their financial capabilities to support the overloaded livestock (Table 2). This leads to livestock numbers exceeding the carrying capacity of grasslands in dry years, creating conditions for grassland degradation. Poor herders are forced to sell large numbers of livestock at bargain prices in the face of drought, which leads to poverty.

In sum, overgrazing in the Xilingol grassland region is a complex problem caused by a combination of factors including (1) herders' strong aspiration to improve their quality of life, (2) faulty grassland leasing policies, (3) decoupling of herders' well-being from grassland conditions, (4) herders' misperceptions about the causes of grassland degradation, and (5) inappropriate strategies for coping with precipitation fluctuations. 


\section{Was the herders' quality of life improving?}

Our results indicate that more than $50 \%$ of herders were satisfied with their overall quality of life. The percentages of herders expressing satisfaction with gender equality and education were even higher than $80 \%$ (Fig. 4). The high life satisfaction of herders may be because of the overall improvement in herders' objective well-being reported by many previous studies (Dong et al. 2015, Huang and Jiang 2017, Shang et al. 2019). This result also demonstrates the success of the government's socioeconomic policies in improving herders' well-being. We also found that the overall life satisfaction of herders in the typical steppes was much lower, at $49 \%$ compared to $72 \%$ in meadow and desert steppes (Fig. 4). Considering that the overall life satisfaction of herders was significantly correlated with income satisfaction (Appendix 4), the lower income satisfaction in the typical steppes (Fig. 4) may be the main reason.

Nearly $50 \%$ of herders still did not feel satisfied with their current quality of life, especially for income. This phenomenon can be explained, at least to some extent, by Easterlin's paradox: economic and material growth does not necessarily increase human happiness because the positive effects of increasing income can be offset by human adaption to the changes and social comparison (Easterlin 1974). For example, herders used to be limited to cow dung fuel and coal as their daily energy sources, but now they have access to electricity generated by wind and solar devices. However, many herders are still unsatisfied with wind and solar energy (Appendix 5) and want the same stable and sufficient electricity supply as those in agricultural and urban areas. As a result of social comparison, herders' demand for highquality energy has increased, leading to dissatisfaction. The increased income inequality of Inner Mongolia over the past 20 years (Shang et al. 2019, Fang et al. 2021) can further exacerbate social comparisons and lead to herders' dissatisfaction. Thus, despite improvement in objective well-being, there are still many herders not satisfied with their current quality of life and wishing to pursue a more prosperous life. However, a higher quality of life requires more livestock to support it, resulting in more grazing pressure on the grasslands.

The privatization of grassland property rights has multiple impacts on herders' quality of life. On the one hand, the land tenure reform in the pastoral areas greatly boosted herders' desire for higher production, leading to the rapid growth of the husbandry economy (Liu 2017). The growth of livestock production provided more disposable income and food for herders. On the other hand, under the system of property privatization, the pasture area per household does not increase with expanding family size. Thus, after several decades, large families with multiple generations would have less and less pasture per household because of the inheritance rule of pasture property rights. The uneven distribution of pasture areas led to the income inequality of herder households. In addition, the uneven distribution of pastures caused by privatization contributed to an increase in pasture rental. According to China's grassland tenure system, grassland rental ensures the transfer of grassland user rights rather than owner rights (Li et al. 2018). Despite the local government's efforts to formalize grassland rental, contracts are usually oral, informal, and short term, which adds to the sense of insecurity regarding the user rights (Zhang et al. 2017, Su et al.
2021). This insecurity not only increases herders' fears about their future income, but also urges them to overuse the rented pastures.

\section{What are the potential deep leverage points to resolve the problem of overgrazing?}

Our results indicate that China's current Forage-Livestock Balance policy has not been effective in preventing overgrazing because of the failed implementation by herders (Fig. 6). The mismatch between herders' desired stocking rates and policystipulated stocking rates has been identified as an important reason (Hou et al. 2013). Our results provide three additional explanations for the herders' resistance to the policy. First, the stocking rates set by the Forage-Livestock Balance policy did not sufficiently consider the large spatial variability in grassland productivity across the broad region. Accurately estimating the productivity of grassland areas owned by different herders would be costly and formidable (Brown et al. 2011). Therefore, many counties simply divided the entire grassland area into a few zones and estimate the average stocking rate for each zone. Also, the government-set maximum stocking rates were not updated annually and thus unable to reflect the effects of precipitation fluctuations. Second, some herders stated that they could not sustain a good living if they strictly adhered to the official stocking rate (Table 3). This is especially true for herders with small grassland areas. The increased economic pressures forced them to overstock. Third, the problem of overgrazing was further exacerbated by the unequal responsibilities and benefits of pasture leasing. Many herders found ways to cheat inspections, whereas others would rather be fined than reduce livestock numbers because having more livestock was still more profitable even with the fine. According to the intervention theory of leverage points (Meadows 1999), directly intervening in herders' use of grasslands by setting maximum allowed stocking rates is a shallow lever that is easy to implement but least effective. To be more effective, grassland environmental policies should also focus on deep leverage points that are more difficult to implement but can bring about transformational change (Abson et al. 2017, Fischer and Riechers 2019). Our results identify three potential deeper levers to address overgrazing (Table 4):

Table 4. Potential leverage points for intervention in the Inner Mongolia grazing system, using typologies from Meadows (1999) and Abson et al. (2017).

\begin{tabular}{|c|c|c|}
\hline $\begin{array}{l}\text { Leverage } \\
\text { type }\end{array}$ & & $\begin{array}{l}\text { Leverage points in the Inner Mongolia grazing } \\
\text { systems }\end{array}$ \\
\hline $\begin{array}{l}\text { Shallow } \\
\text { leverage } \\
\text { points }\end{array}$ & $\begin{array}{c}\text { Parameters } \\
\text { Feedbacks }\end{array}$ & $\begin{array}{l}\text { To set the maximum allowed stocking rates. } \\
\text { To reconnect the long-term health of rented } \\
\text { grasslands with herders' livelihoods. }\end{array}$ \\
\hline $\begin{array}{l}\text { Deep } \\
\text { leverage } \\
\text { points }\end{array}$ & Design & $\begin{array}{l}\text { To improve the grassland governance system by } \\
\text { integrating top-down policy and herder self- } \\
\text { governance. To get herders involved in developing } \\
\text { holistic livestock management strategies that are } \\
\text { both economically profitable and ecologically } \\
\text { sustainable. } \\
\text { To reduce poverty and inequity. }\end{array}$ \\
\hline
\end{tabular}


1. To reduce poverty and inequity (change the intention of the system). Many herders tend to overstock because of increased economic pressures or aspirations for a better life. Thus, for herders to use grasslands in a sustainable way, policies need to be designed not only to eradicate the poverty of herders, but also to reduce the income gap between pastoral and urban areas.

2. To improve the grassland governance system (change the rules of the system). The Chinese government has been focusing on top-down policy regulation and privatization of pasture property rights to address grassland degradation. Our results show that both strategies have been ineffective on the ground. Herder self-governance seems to be a missing part of the solution because this strategy allows for the full integration of herders' knowledge into grassland management. For example, Li et al. (2007) found that comanagement of grasslands and livestock among a few households in Xilingol promoted sustainable use of grasslands. However, whether this strategy can be effective on a large scale remains to be tested.

3. To reconnect the long-term health of rented grasslands with herders' livelihoods (reconstruct feedbacks). In the context of rapid urbanization, more and more herders are leaving the grasslands and renting out their pastures. The renters tend to overstock rented pastures to maximize short-term profits. Without a strong link between herders' incomes and the rented grassland degradation, herders are not likely to adopt strategies to ameliorate grassland degradation.

4. To get herders involved in developing holistic livestock management strategies that are both economically profitable and ecologically sustainable (change the structure of information flows). Herders need to have a more comprehensive and science-supported understanding of the main causes of grassland degradation and learn how to cope with droughts in an adaptive manner. Learning and experimenting with grassland management strategies can help introduce new information flows to the structure of grazing systems as a significant design-level leverage point (Tourangeau and Sherren 2020). Toward this end, transdisciplinary landscape sustainability studies are needed to bring together researchers and herders and bridge science with traditional ecological knowledge.

\section{CONCLUSIONS}

In this study we investigated the underlying causes of overgrazing in the Xilingol grassland of Inner Mongolia by systematically examining herders' livestock decision-making processes. Based on semi-structured interviews with herders, we found that herders had a strong zeal for improving their quality of life as income disparity increased among herders and between herders and urban dwellers. Herders' misperceptions about the key drivers of grassland degradation and the decoupling of herders' well-being from grassland ecological conditions prevented them from adopting proactive strategies to address the problem of grassland degradation. Herders' improper strategies to cope with drought also contributed to overgrazing. Our results suggest that the current grassland policies, which were intended to control livestock numbers by stipulating the maximum stocking rate, are shallow intervention strategies that are ineffective. The sustainability transition of Inner Mongolian grasslands can only be achieved by incorporating deeper leverage points for intervention, including reducing poverty and inequity, improving the grassland property system, reconnecting the long-term grassland health to herders' livelihoods, and collaborating with herders to develop holistic livestock management strategies that balance short-term gains and long-term ecological integrity.

Responses to this article can be read online at: https://www.ecologyandsociety.org/issues/responses. php/12878

\section{Acknowledgments:}

We thank Wenjun Li, Xiangyang Hou, Jianming Niu, and Qing Zhang for their comments and suggestions on this work. We also thank Ang Li and Yang Liu for their assistance with the fieldwork and data analysis. This research was supported by grants from the National Basic Research Program of China (2014CB954303) and National Natural Science Foundation of China (41901142).

\section{Data Availability:}

The data that support the findings of this study are available on request from the corresponding author $(\mathrm{JW})$. None of the data are publicly available because they contain information that could compromise the privacy of research participants.

\section{LITERATURE CITED}

Abson, D. J., J. Fischer, J. Leventon, J. Newig, T. Schomerus, U. Vilsmaier, H. von Wehrden, P. Abernethy, C. D. Ives, N. W. Jager, and D. J. Lang. 2017. Leverage points for sustainability transformation. Ambio 46:30-39. https://doi.org/10.1007/ s13280-016-0800-y

Bai, Y., X. Han, J. Wu, Z. Chen, L. Li. 2004. Ecosystem stability and compensatory effects in the Inner Mongolia grassland. Nature 431:181-184. https://doi.org/10.1038/nature02850

Bao, G., Z. Qin, Y. Bao, Y. Zhou, W. Li, and A. Sanjjav. 2014. NDVI-based long-term vegetation dynamics and its response to climatic change in the Mongolian Plateau. Remote Sensing 6:8337-8358. https://doi.org/10.3390/rs6098337

Bernard, H. R. 2017. Research methods in anthropology: qualitative and quantitative approaches. Rowman \& Littlefield, Lanham, Maryland, USA.

Biró, M., Z. Molnár, D. Babai, A. Dénes, A. Fehér, S. Barta, L. Sáfián, K. Szabados, A. Kiš, L. Demeter, and K. Öllerer. 2019. Reviewing historical traditional knowledge for innovative conservation management: a re-evaluation of wetland grazing. Science of the Total Environment 666:1114-1125. https://doi. org/10.1016/j.scitotenv.2019.02.292

Braun, V., and V. Clarke. 2006. Using thematic analysis in psychology. Qualitative Research in Psychology 3:77-101. https:// doi.org/10.1191/1478088706qp063oa 
Brown, C., S. Waldron, and Z. Yutian. 2011. Policy settings to combat grassland degradation and promote sustainable development in western China. Pages 105-114 in D. R. Kemp, and D. L. Michalk, editors. Proceedings of the Australian Centre for International Agricultural Research (ACIAR) No. 134. ACIAR, Canberra, Australia.

Carvalho, F. P. 2017. Pesticides, environment, and food safety. Food and Energy Security 6:48-60. https://doi.org/10.1002/ $\underline{\text { fes } 3.108}$

Cash, D. W., W. C. Clark, F. Alcock, N. M. Dickson, N. Eckley, D. H. Guston, J. Jäger, and R. B. Mitchell. 2003. Knowledge systems for sustainable development. Proceedings of the National Academy of Sciences 100:8086-8091. https://doi.org/10.1073/ pnas. 1231332100

Clay, N., and K. S. Zimmerer. 2020. Who is resilient in Africa's Green Revolution? Sustainable intensification and climate smart agriculture in Rwanda. Land Use Policy 97:104558. https://doi. org/10.1016/j.landusepol.2020.104558

Cumming, G. S., and G. Epstein. 2020. Landscape sustainability and the landscape ecology of institutions. Landscape Ecology 35:2613-2628. https://doi.org/10.1007/s10980-020-00989-8

Díaz, S., U. Pascual, M. Stenseke, B. Martí-Lóez, R. T. Watson, Z. Molnár, R. Hill, K. M. A. Chan, I. A. Baste, K. A. Brauman, S. Polasky, A. Church, M. Lonsdale, A. Larigauderie, P. W. Leadley, A. P. E. van Oudenhoven, F. van der Plaat, M. Schröter, S. Lavorel, Y. Aumeeruddy-Thomas, E. Bukvareva, K. Davies, S. Demissew, G. Erpul, P. Failler, C. A. Guerra, C. L. Hewitt, H. Keune, S. Lindley, and Y. Shirayama. 2018. Assessing nature's contributions to people. Science 359:270-272. https://doi. org/10.1126/science.aap8826

Dong, X., G. Dai, S. Ulgiati, R. Na, X. Zhang, M. Kang, and X. Wang. 2015. On the relationship between economic development, environmental integrity and well-being: the point of view of herdsmen in northern China grassland. PloS ONE 10:e134786. https://doi.org/10.1371/journal.pone.0134786

Dubois, P. 2002. Moral hazard, land fertility and sharecropping in a rural area of the Philippines. Journal of Development Economics 68:35-64. https://doi.org/10.1016/S0304-3878(02) $\underline{00005-6}$

Easterlin, R. A. 1974. Does economic growth improve the human lot? Some empirical evidence. Pages 89-125 in P. A. David and M. W. Reder, editors. Nations and households in economic growth. Academic Press, New York, New York, USA. https://doi. org/10.1016/B978-0-12-205050-3.50008-7

Elo, S., and H. Kyngä. 2008. The qualitative content analysis process. Journal of Advanced Nursing 62:107-115. https://doi. org/10.1111/j.1365-2648.2007.04569.x

Fang, J., Y. Bai, and J. Wu. 2015. Towards a better understanding of landscape patterns and ecosystem processes of the Mongolian Plateau. Landscape Ecology 30:1573-1578. https://doi.org/10.1007/ s10980-015-0277-2

Fang, X., J. Wu, and C. He. 2021. Assessing human-environment system sustainability based on Regional Safe and Just Operating Space: The case of the Inner Mongolia grassland. Environmental
Science \& Policy 116:276-286. https://doi.org/10.1016/j. envsci.2020.12.007

Fang, X., B. Zhou, X. Tu, Q. Ma, and J. Wu. 2018. "What kind of a science is sustainability science?" An evidence-based reexamination. Sustainability 10:1478. https://doi.org/10.3390/ $\underline{\text { su10051478 }}$

Fischer, J., and M. Riechers. 2019. A leverage points perspective on sustainability. People and Nature 1:115-120 https://doi. org/10.1002/pan3.13

Frazier, A. E., B. A. Bryan, A. Buyantuev, L. Chen, C. Echeverria, P. Jia, L. Liu, Q. Li, Z. Ouyang, J. Wu, W.-N. Xiang, J. Yang, L. Yang, and S. Zhao. 2019. Ecological civilization: perspectives from landscape ecology and landscape sustainability science. Landscape Ecology 34:1-8. https://doi.org/10.1007/s10980-019-00772-4

Hardin, G. 1968. The tragedy of the commons: the population problem has no technical solution; it requires a fundamental extension in morality Science 162:1243-1248. https://doi. org/10.1126/science.162.3859.1243

Hilker, T., E. Natsagdorj, R. H. Waring, A. Lyapustin, and Y. Wang. 2014. Satellite observed widespread decline in Mongolian grasslands largely due to overgrazing. Global Change Biology 20:418-428. https://doi.org/10.1111/gcb.12365

Hou, X., Y. Yin, X. Yun, X. Li, and Y. Ding. 2013b. Herders 'stocking rates and shift of grass-animal balance model in northern grassland of China. Chinese Journal of Grassland $35: 1-11$.

Huang, G., and Y. Jiang. 2017. Urbanization and socioeconomic development in Inner Mongolia in 2000 and 2010: a GIS analysis. Sustainability 9:235. https://doi.org/10.3390/su9020235

Jiang, G., X. Han, and J. Wu. 2006. Restoration and management of the Inner Mongolia grassland require a sustainable strategy. Ambio 35:269-270. https://doi.org/10.1579/06-S-158.1

John, R., J. Chen, Y. Kim, Z. Ou-yang, J. Xiao, H. Park, C. Shao, Y. Zhang, A. Amarjargal, O. Batkhshig, and J. Qi. 2016. Differentiating anthropogenic modification and precipitationdriven change on vegetation productivity on the Mongolian Plateau. Landscape Ecology 31:547-566. https://doi.org/10.1007/ $\underline{\text { s10980-015-0261-X }}$

Karnieli, A., Y. Bayarjargal, M. Bayasgalan, B. Mandakh, C. Dugarjav, J. Burgheimer, S. Khudulmur, S. N. Bazha, and P. D. Gunin. 2013. Do vegetation indices provide a reliable indication of vegetation degradation? A case study in the Mongolian pastures. International Journal of Remote Sensing 34:6243-6262. https://doi.org/10.1080/01431161.2013.793865

Li, A., J. Wu, and J. Huang. 2012. Distinguishing between humaninduced and climate-driven vegetation changes: a critical application of RESTREND in Inner Mongolia. Landscape Ecology 27:969-982. https://doi.org/10.1007/s10980-012-9751-2

Li, A., J. Wu, X. Zhang, J. Xue, Z. Liu, X. Han, and J. Huang. 2018. China's new rural "separating three property rights" land reform results in grassland degradation: evidence from Inner Mongolia. Land Use Policy 71:170-182. https://doi.org/10.1016/ j.landusepol.2017.11.052 
Li, W. J., S. H. Ali, and Q. Zhang. 2007. Property rights and grassland degradation: a study of the Xilingol pasture, Inner Mongolia, China. Journal of Environmental Management 85:461-470. https://doi.org/10.1016/j.jenvman.2006.10.010

Li, W., and L. Huntsinger. 2011. China's grassland contract policy and its impacts on herder ability to benefit in Inner Mongolia: tragic feedbacks. Ecology and Society 16(2):1. https://doi. org/10.5751/ES-03969-160201

Li, W., and Y. Li. 2012. Managing rangeland as a complex system: how government interventions decouple social systems from ecological systems. Ecology and Society 17(1):9. https://doi. org/10.5751/ES-04531-170109

Liao, C., A. Agrawal, P. E. Clark, S. A. Levin, and D. I. Rubenstein. 2020a. Landscape sustainability science in the drylands: mobility, rangelands and livelihoods. Landscape Ecology 35:2433-2447. https://doi.org/10.1007/s10980-020-01068-8

Liao, C., J. Qiu, B. Chen, D. Chen, B. Fu, M. Georgescu, C. He, G. D. Jenerette, X. Li, X. Li, B. Qiuying, P Shi, and J. Wu. 2020b. Advancing landscape sustainability science: theoretical foundation and synergies with innovations in methodology, design, and application. Landscape Ecology 35:1-9. https://doi. org/10.1007/s10980-020-00967-0

Liu, M. 2017. China's grassland policies and the Inner Mongolian grassland system. Dissertation. Wageningen University, Wageningen, Netherlands. [online] URL: https://edepot.wur. $\underline{\mathrm{nl} / 399371}$

Liu, M., L. Dries, W. Heijman, J. Huang, and X. Deng. 2015. Tragedy of the commons or tragedy of privatization? The impact of land tenure reform on grassland condition in Inner Mongolia, China. Paper presented at International Association of Agricultural Economists Conference, Milan, Italy. https://doi. org/10.22004/ag.econ.212052

Liu, Y. Y., J. P. Evans, M. F. McCabe, R. A. M. de Jeu, A. I. J. M. van Dijk, A. J. Dolman, and I. Saizen. 2013. Changing climate and overgrazing are decimating Mongolian steppes. PLoS ONE 8:e57599. https://doi.org/10.1371/journal.pone.0057599

Meadows, D. 1998. Indicators and information systems for sustainable development. Sustainability Institute, Hartland, Vermont, USA.

Meadows, D. 1999. Leverage points: place to intervene in a system. Sustainability Institute, Hartland, Vermont, USA.

Miao, L. J., Q. Liu, R. Fraser, B. He, and X. F. Cui. 2015. Shifts in vegetation growth in response to multiple factors on the Mongolian Plateau from 1982 to 2011. Physics and Chemistry of the Earth 87-88:50-59. https://doi.org/10.1016/j.pce.2015.07.010

Millennium Ecosystem Assessment (MA). 2005. Ecosystems and human well-being: synthesis. Island Press, Washington, D.C., USA. [online] URL: https://www.millenniumassessment.org/ documents/document.356.aspx.pdf

Mu, S. J., S. X. Zhou, Y. Chen, J. Li, W. Ju, and I. O. A. Odeh. 2013. Assessing the impact of restoration-induced land conversion and management alternatives on net primary productivity in Inner Mongolian grassland, China. Global and
Planetary Change 108:29-41. https://doi.org/10.1016/j. gloplacha.2013.06.007

Opdam, P., S. Luque, J. Nassauer, P. H. Verburg, and J. Wu. 2018. How can landscape ecology contribute to sustainability science? Landscape Ecology 33:1-7. https://doi.org/10.1007/s10980-018-0610-7

Ostrom, E. 1990. Governing the commons: the evolution of institutions for collective action. Cambridge University Press, Cambridge, UK.

Reynolds, J. F., D. M. S. Smith, E. F. Lambin, B. Turner, M. Mortimore, S. P. Batterbury, T. E. Downing, H. Dowlatabadi, R. J. Fernádez, J. E. Herrick, E. Huber-Sannwald, H. Jiang, R. Leemans, T. Lynam, F. T. Maestre, M. Ayarza, and B. Walker. 2007. Global desertification: building a science for dryland development. Science 316:847-851. https://doi.org/10.1126/ science. 1131634

Robinson, B. E., P. Li, and X. Hou. 2017. Institutional change in social-ecological systems: the evolution of grassland management in Inner Mongolia. Global Environmental Change 47:64-75. https://doi.org/10.1016/j.gloenvcha.2017.08.012

Shang, C., T. Wu, G. Huang, and J. Wu. 2019. Weak sustainability is not sustainable: socioeconomic and environmental assessment of Inner Mongolia for the past three decades. Resources, Conservation and Recycling 141:243-252. https://doi.org/10.1016/ j.resconrec.2018.10.032

Su, L., J. Tang, and H. Qiu. 2021. Intended and unintended environmental consequences of grassland rental in pastoral China. Journal of Environmental Management 285:112126. https://doi.org/10.1016/j.jenvman.2021.112126

Sun, X., L. Gao, H. Ren, Y. Ye, A. Li, M. Stafford-Smith, J. D. Connor, J. Wu, B. A. Bryan. 2018. China's progress towards sustainable land development and ecological civilization. Landscape Ecology 33:1647-1653. https://doi.org/10.1007/ s10980-018-0706-0

Tong, C., J. Wu, S. Yong, J. Yang, and W. Yong. 2004. A landscapescale assessment of steppe degradation in the Xilin River Basin, Inner Mongolia, China. Journal of Arid Environments 59:133-149. https://doi.org/10.1016/j.jaridenv.2004.01.004

Tourangeau, W., and K. Sherren. 2020. Leverage points for sustainable wool production in the Falkland Islands. Journal of Rural Studies 74:22-33. https://doi.org/10.1016/j.jrurstud.2019.11.008

Wang, J., D. G. Brown, and J. Chen. 2013. Drivers of the dynamics in net primary productivity across ecological zones on the Mongolian Plateau. Landscape Ecology 28:725-739. https://doi. org/10.1007/s10980-013-9865-1

Wu, J. 2013. Landscape sustainability science: ecosystem services and human well-being in changing landscapes. Landscape Ecology 28:999-1023. https://doi.org/10.1007/s10980-013-9894-9

Wu, J. 2021. Landscape sustainability science (II): core questions and key approaches. Landscape Ecology 36:2453-2485. https:// doi.org/10.1007/s10980-021-01245-3

Wu, J., and O. L. Loucks. 1992. The Xilingol Grassland. Pages 67-84 in U.S. National Research Council, editor. Grasslands and 
grassland sciences in Northern China. National Academy Press, Washington, D.C. USA.

Wu, J., Q. Zhang, A. Li, and C. Liang. 2015. Historical landscape dynamics of Inner Mongolia: patterns, drivers, and impacts. Landscape Ecology 30:1579-1598. https://doi.org/10.1007/ $\underline{\text { s10980-015-0209-1 }}$

Wu, X., P. Li, C. Jiang, P. Liu, J. He, and X. Hou. 2014. Climate changes during the past 31 years and their contribution to the changes in the productivity of rangeland vegetation in the Inner Mongolian typical steppe. Rangeland Journal 36:519-526. https:// doi.org/10.1071/RJ14054

Zhang, M., L. Zhang, Y. Zhang, Y. Xu, and J. Chen. 2017. Pastureland transfer as a livelihood adaptation strategy for herdsmen: a case study of Xilingol, Inner Mongolia. Rangeland Journal 39:179-187. https://doi.org/10.1071/RJ15121

Zhang, Q., A. Buyantuev, X. Fang, P. Han, A. Li, F. Y. Li, C. Liang, Q. Liu, Q. Ma, J. Niu, C. Shang, Y. Yan, and J. Zhang. 2020. Ecology and sustainability of the Inner Mongolian Grassland: looking back and moving forward. Landscape Ecology 35:2413-2432. https://doi.org/10.1007/s10980-020-01083-9

Zhao, X., H. F. Hu, H. Shen, D. Zhou, L. Zhou, R. B. Myneni, and J. Fang. 2015. Satellite-indicated long-term vegetation changes and their drivers on the Mongolian Plateau. Landscape Ecology 30:1599-1611. https://doi.org/10.1007/s10980-014-0095y

Zhao, Y., Z. Liu, and J. Wu. 2020. Grassland ecosystem services: a systematic review of research advances and future directions. Landscape Ecology 35:793-814. https://doi.org/10.1007/ s10980-020-00980-3 
Appendix 1. The basic demographic information of the interviewed herders compared with associated data from the Inner Mongolia Statistical Yearbook.

\begin{tabular}{llll}
\hline Variables & Categories & $\begin{array}{l}\text { Number } \\
\text { respondents }(\%)\end{array}$ & $\begin{array}{l}\text { of } \\
\text { statistical } \\
\text { yearbook }(\%)\end{array}$ \\
\hline \multirow{2}{*}{ Gender } & Female & $31 \%$ & $49 \%$ \\
& Male & $69 \%$ & $51 \%$ \\
Age & 18 & $2 \%$ & $16 \%$ \\
& $18-34$ & $26 \%$ & $28 \%$ \\
\multirow{5}{*}{ Nationality } & $35-59$ & $67 \%$ & $44 \%$ \\
& $>60$ & $5 \%$ & $12 \%$ \\
\multirow{5}{*}{ Education } & Mongolian & $71 \%$ & $67 \%$ \\
& Han & $29 \%$ & $32 \%$ \\
& Primary school & $28 \%$ & $30 \%$ \\
& Secondary school & $60 \%$ & $59 \%$ \\
& College and university & $12 \%$ & $11 \%$ \\
\hline
\end{tabular}


Appendix 2. Semi-structured interview guides.

\section{Demographic information (Closed-ended)}

\begin{tabular}{|l|l|l|}
\hline Name: & Gender: & Age: \\
\hline Nationality: & Education: & Occupation: \\
\hline Basic livestock management information (Closed-ended) \\
\hline Inherent pasture area: & Rented pasture area: & Livestock breeds: \\
\hline Livestock numbers: & Supplementary forage per year: & Supplementary concentrates per year: \\
\hline
\end{tabular}

The maximum stocking rates stipulated by the Forage-Livestock Balance policy:

\section{Basic livelihood information (Closed-ended)}

\begin{tabular}{l|l|l}
\hline Livestock net income: & Income from other sources: & Loan amount:
\end{tabular}

Annual expenditures on food, clothing, traffic, heating, education, and medical treatment:

Herder's perceptions of grassland ecological changes (Closed-ended + Open-ended)

1. Overall, how has the grassland vegetation grown over the past 20 years? (Closed-ended)
(A) Better
(B) Worse
(C) No change
(D) Unclear

2. What indicators do you use to judge grassland degradation? (Closed-ended)
(A) Plant species
(B) Grass height
(C) Desertification
(D) Grass productivity
(E) Grass density

Herder's subjective evaluation of their well-being conditions (Closed-ended + Open-ended)

3. Overall, are you satisfied with your current qualify of life? (Closed-ended)
(A) Very satisfied
(B) Satisfied
(C) Not too bad
(D) Unsatisfied

4. Herders' subjective evaluation of the following eight wellbeing dimensions (Closed-ended + Openended)

(1) Income: are you satisfied with your current level of income, why?
(A) Very satisfied
(B) Satisfied
(C) Not too bad
(D) Unsatisfied

(2) Food security: are you satisfied with the convenience, safety, or price of food, why?
(A) Very satisfied
(B) Satisfied
(C) Not too bad
(D) Unsatisfied

(3) Health care: are you satisfied with local medical facilities and the health status of your family, why?
(A) Very satisfied
(B) Satisfied
(C) Not too bad
(D) Unsatisfied

(4) Gender equality: are you satisfied with the current status and division of labor between women and men in the family, why?
(A) Very satisfied
(B) Satisfied
(C) Not too bad
(D) Unsatisfied 
(5) Education: are you satisfied with your children's education level and access to high-quality education, why?
(A) Very satisfied
(B) Satisfied
(C) Not too bad
(D) Unsatisfied

(6) Water \& sanitation: are you satisfied with the drinking water and livestock drinking water, why?
(A) Very satisfied
(B) Satisfied
(C) Not too bad
(D) Unsatisfied

(7) Access to energy: are you satisfied with your current home energy supply, and why?
(A) Very satisfied
(B) Satisfied
(C) Not too bad
(D) Unsatisfied

(8) Social equity: are you satisfied with social equality, and why?
(A) Very satisfied
(B) Satisfied
(C) Not too bad
(D) Unsatisfied

Herder's perceptions and understandings of herder-grassland relationships (Closed-ended + Openended)

5. What benefits do you think grasslands can provide for you? (Closed-ended)
(A) Economic benefits
(B) Food provisioning
(C) Sandstorm prevention
(D) Air purification
(E)

Eco-tourism (F) Visual aesthetic

6. What do you think are the main causes of grassland degradation? (Open-ended)

7. Do you think grassland degradation is related to overgrazing? to what extent? (Closed-ended)
(A) Very relevant
(B) Relevant
(C) Weak relevant
(D) Irrelevant

8. Why do herders overgraze despite knowing its negative effects on grasslands? (Open-ended)

Herder's livestock management strategies and views on grassland environmental policies (Closedended + Open-ended)

12. How do you decide the livestock numbers to be sold and reserved each year? (Open-ended)

13. To prevent grassland degradation, the government has implemented several grassland environmental policies, such as the Fencing Program, Forage-Livestock Balance policy, and Forbidden Grazing and Rotational Grazing programs. (Closed-ended + Open-ended)

(1) Do you think the Fencing Program is reasonable or unreasonable, Why?

(2) Do you think the Forage-Livestock Balance policy is reasonable or unreasonable, Why?

(3) Do you think the Forbidden Grazing and Rotational Grazing programs are reasonable or unreasonable, Why? 
Appendix 3. The percentages of respondents who perceive overgrazing as a factor for grassland degradation under different genders, ages, nationalities, and education.

\begin{tabular}{llll}
\hline Variables & Categories & $\begin{array}{l}\text { Number of } \\
\text { respondents }\end{array}$ & $\begin{array}{l}\text { Percentage of respondents who } \\
\text { perceive overgrazing as a factor } \\
\text { of grassland degradation (\%) }\end{array}$ \\
\hline \multirow{2}{*}{ Gender } & Female & 35 & $20 \%$ \\
& Male & 78 & $24 \%$ \\
Age & $18-34$ & 22 & $14 \%$ \\
& $35-59$ & 85 & $26 \%$ \\
Nationality & $>60$ & 6 & $17 \%$ \\
& Mongolian & 79 & $19 \%$ \\
Education & Han & 34 & $33 \%$ \\
& Primary school & 31 & $29 \%$ \\
& Secondary school & 71 & $24 \%$ \\
& College and university & 11 & $9 \%$ \\
\hline
\end{tabular}


Appendix 4. The Spearman correlations between herders' overall life satisfaction and the eight individual categories $(* p<0.05 ; * * p<0.01)$.

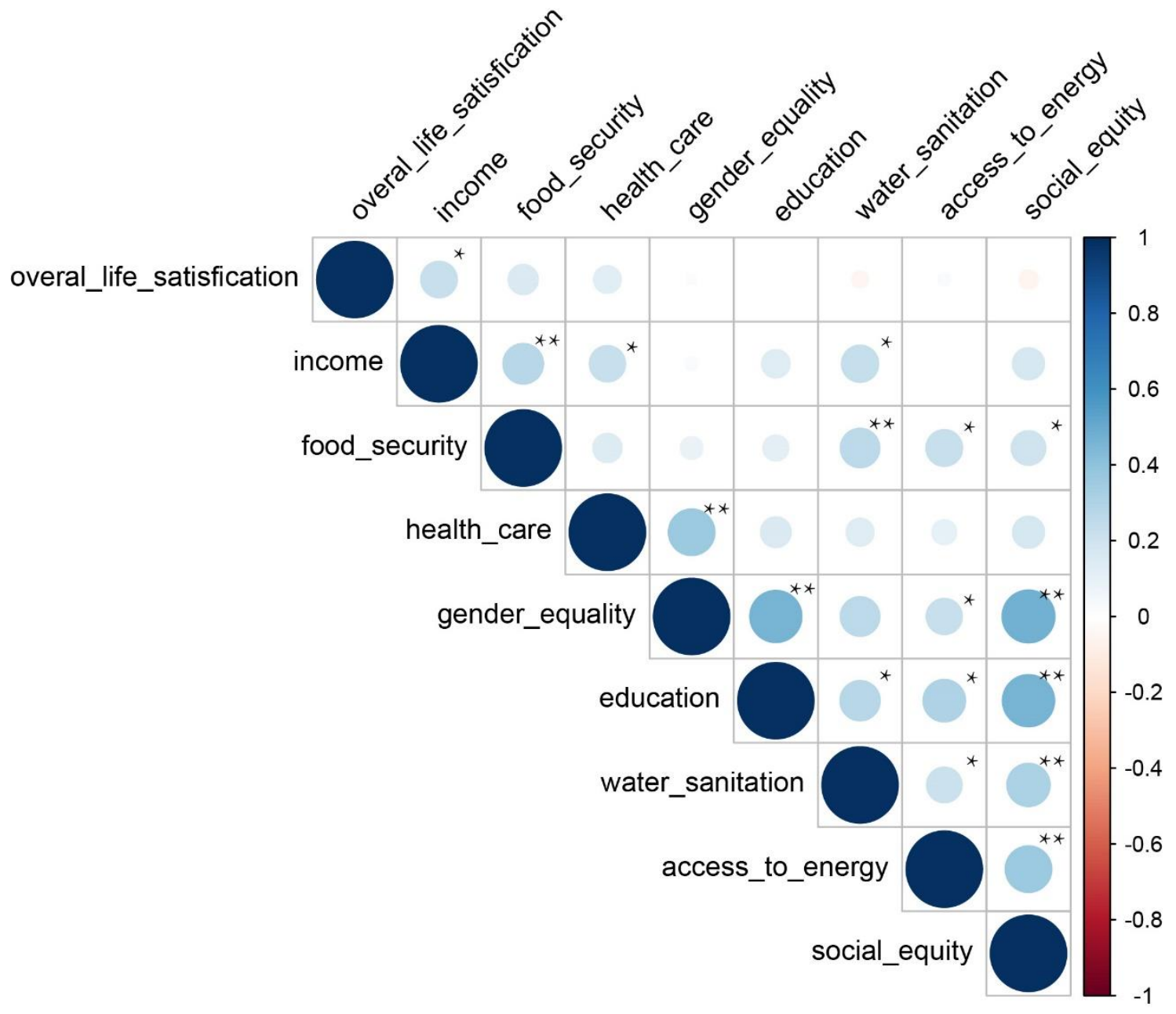


Appendix 5. Reasons for herders' dissatisfaction with the eight dimensions of wellbeing.

\begin{tabular}{lll}
\hline $\begin{array}{l}\text { Eight wellbeing } \\
\text { dimensions }\end{array}$ & Reasons for dissatisfaction & $\begin{array}{c}\text { Frequency } \\
\text { (n=107) }\end{array}$ \\
\hline 1. Income & The income is too low to support a good life. & $41 \%$ \\
2. Food security & $\begin{array}{l}\text { Herders are worried about the abuse of pesticides and fertilizers } \\
\text { in vegetables and fruits. }\end{array}$ & $12 \%$ \\
& $\begin{array}{l}\text { Vegetables and fruits in pastoral areas are expensive and } \\
\text { inconvenient to purchase. }\end{array}$ & $11 \%$ \\
& $\begin{array}{l}\text { Family members suffered from diseases. } \\
\text { The pollution from coal mining threatens their health }\end{array}$ & $8 \%$ \\
& $\begin{array}{l}\text { It is not convenient for their children to get educated in the } \\
\text { 4. Education }\end{array}$ & $6 \%$ \\
& county because of the long commute. & $6 \%$ \\
5. Gender equity & Women usually have to do more livestock work than men. & $2 \%$ \\
6. Water and sanitation & $\begin{array}{l}\text { The water quality is poor with high salinity. } \\
\text { The water volume is insufficient for drinking livestock. }\end{array}$ & $16 \%$ \\
& Coal mining is polluting and depleting their water sources. & $5 \%$ \\
7. Access to energy & $\begin{array}{l}\text { The electricity generated by solar and wind is unstable and } \\
\text { insufficient for daily use. }\end{array}$ & $15 \%$ \\
8. Social equity & Corruption of local officers leads to social inequity. & $3 \%$ \\
\hline
\end{tabular}

